Крюкова Людмила

здобувач ступеня $\mathrm{PhD}$ кафедри вікової та педагогічної психології Рівненського державного гуманітарного університету

ORCID iD: 0000-0001-6572-6214

DOI https://doi.org/10.35619/prap_rv.vi13.123

\title{
ВПЛИВ ЕМОЦЙНОЇ СФЕРИ НА ПРОЦЕСИ АДАПТАЦІЇ ПЕРШОКЛАСНИКА ДО НАВЧАЛЬНОГО ПРОЦЕСУ
}

Анотація. У статті розкриті особливості адаптащії молодшого иколяра до навчального процесу. Проаналізовано останні дослідження з проблеми. Виявлено, ще дана проблема набула суттєвого значення на сучасному етапі розвитку педагогічної науки. Зроблено висновок, щчо рівень розвитку емоційної сфери дитини визначає, наскільки адаптованою буде дана дитина до відповідного середовища. Визначені причини та форми дезадаптації першокласника до шкільного навчання. Виділені основні аспекти адаптаціі школяра. Розглянуто основні складові адаптивності дитини до шкільного навчання. Вивчено, щуо стан емочійного дискомфорту є однією з причин шкільної дезадаптації та порушення психічного здоров'я школяра. Встановлено, що адаптаційний процес буде відбуватися швидше та ефективніше при позитивному розвитку емоційної сфери першокласника. Запропоновано для підвищення рівня адаптації на основі розвитку емочійної сфери проводити т.з. кольорові експерименти, які допоможуть сформувати позитивне ставлення першокласника до навчання в школі. Такі експерименти за допомогою кольору можуть ефективно вплинути на емочійну сферу першокласника, сформувати запас позитивних емочій щзодо навчального процесу та підвищити рівень икільної адаптації.

Ключові слова: адаптація, емоційна сфера, емоційна стабільність, дезадаптація, навчання, першокласник.

Постановка проблеми. На сучасному етапі розвитку педагогічної науки та шкільної практики суттєвого значення набуває проблема адаптації першокласника до шкільного навчання на рівні розвитку емоційної сфери.

Емоційна сфера є одним із визначальних чинників, яка суттєво впливає на адаптацію у відповідному середовищі існування та, особливо, першокласника у новому соціальному середовищі. Адже саме те, наскільки адаптованою буде дитина, яка змінює свій уклад життя, рід діяльності та соціум, впливає рівень розвитку емоційної сфери даної дитини та ії емоційна стабільність. Початок шкільного життя - це початок особливої навчальної діяльності, що вимагає від дитини і значного розумового напруження, і великої фізичної витривалості. Молодший шкільний вік - найбільш сприятливий період розвитку емоційної сфери та культури почуттів особистості. Дитина знаходиться в постійному розвитку, тому взаємини з нею повинні визначатися віковими особливостями. На різних вікових етапах розвитку спостерігаються різні переживання. Саме тому дуже важливим та одночасно складним вважається адаптаційний період і не кожен учень його успішно проходить. Таким чином, можуть виникнути проблеми соціалізації унаслідок недостатньої готовності до школи та розвитку дезадаптації дитини.

Аналіз останніх досліджень 3 проблеми. Особливості адаптаційних процесів у школярів з психофізіологічних позицій у цілому мало вивчається в експериментальних та інноваційних умовах навчання за новими педагогічними технологіями, а також у період впровадження нових експериментальних програм. Оцінка їхньої ефективності здійснюється лише за педагогічними критеріями, які $\epsilon$ нечіткими та відносними. Зовсім відсутнє врахування чинників, що впливають на формування певних функціональних станів в умовах навчання, а також на психічне та фізичне здоров'я учнів. У результаті підвищуються показники дезадаптації учнів - відчуття пригніченості, формування негативних емоцій, зниження активності. (Сисоєнко, 2005)

Випуск 13, 2019. Збірник наукових праць РДГУ 
Шкільна адаптація розуміється в сучасній психолого-педагогічній літературі як складний процес пристосування дитини до школи, а також школи до дитини. Процес адаптації вивчався такими науковцями: Антропова, Кольцова, Хрипкова (в галузі медицини); Божович, Вострокнутов, Грецов, Мороз, Цилєв, Чуткіна, Яценко та іншими дослідниками. За результатами їх досліджень можна зробити висновок, що процес адаптації - це творчий та активний комунікативний процес, в якому люди як особистості долають певні труднощі та формують нові способи взаємодії з різними елементами соціального середовища, а не пасивно пристосовуються до колективу. У цілому у дітей процес адаптації закінчується у першому півріччі навчального процесу. При цьому потрібно пам'ятати, що у процесі адаптації визначаються основні адаптаційні труднощі учнів-новачків у новому соціальному середовищі школи, що може призвести до подальшої їх дезадаптації (табл. 1).

\section{Причини дезадаптації першокласника}

Таблиияя 1

\begin{tabular}{|c|c|c|}
\hline Види труднощів & $\begin{array}{c}\text { Категорія дітей, яка найчастіше } \\
\text { відчуває дану проблему }\end{array}$ & $\begin{array}{c}\text { Результат впливу даного } \\
\text { виду труднощів }\end{array}$ \\
\hline Новий режим дня & $\begin{array}{l}\text { діти, які не відвідували дошкільні } \\
\text { установи }\end{array}$ & $\begin{array}{l}\text { відставання в розвитку рівня } \\
\text { довільної регуляції поведінки, } \\
\text { організованості }\end{array}$ \\
\hline $\begin{array}{l}\text { Соціальний статус } \\
\text { в } \quad \text { класному } \\
\text { колективі }\end{array}$ & $\begin{array}{l}\text { діти, у яких відсутній досвід } \\
\text { перебування в дитячому колективі, } \\
\text { неадекватне усвідомлення свого } \\
\text { статусу в групі однолітків }\end{array}$ & $\begin{array}{l}\text { пригніченість, або, навпаки, } \\
\text { сильна збудженість }\end{array}$ \\
\hline $\begin{array}{l}\text { Взаємини } \\
\text { учителем }\end{array}$ & $\begin{array}{l}\text { діти, у яких є проблеми у спілкуванні } \\
3 \quad \text { дорослими, які позбавлені } \\
\text { індивідуального підходу }\end{array}$ & $\begin{array}{l}\text { нестійкість й вузькість уваги, } \\
\text { окремі розлади пам'яті }\end{array}$ \\
\hline $\begin{array}{l}\text { Взаємини } \\
\text { родині }\end{array}$ & $\begin{array}{l}\text { діти, у яких присутня конфліктна } \\
\text { ситуація в сім'ї, низький освітній } \\
\text { рівень батька і матері, неповна сім'я }\end{array}$ & $\begin{array}{l}\text { функціональна неготовність до } \\
\text { навчання в школі }\end{array}$ \\
\hline
\end{tabular}

Адаптована дитина легко долає певні соціальні та комунікативні труднощі, відповідає рівням сформованості психологічних властивостей та вимогам і нормам певного середовища, у цілому пристосована до повноцінного розвитку в ньому, а також розвиває власний фізичний та інтелектуальний потенціал. При дослідженні адаптаційного потенціалу особистості учнів необхідно враховувати основні чинники, які впливають на успішну адаптацію, або ж спричинюють дезадаптації школяра. Розглянемо дані чинники у вигляді авторської схеми (рис. 1).

генетичні фактори

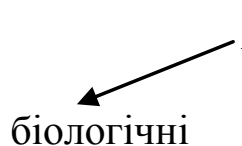
індивідуально-типологічні характеристики особистості соматична ослабленість

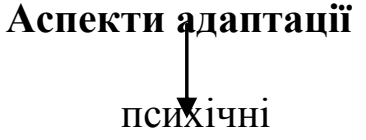

особливості емоційно-вольової сфери дитини

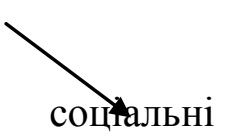

ситуація в родині

стосунки 3 дітьми підхід вчителя

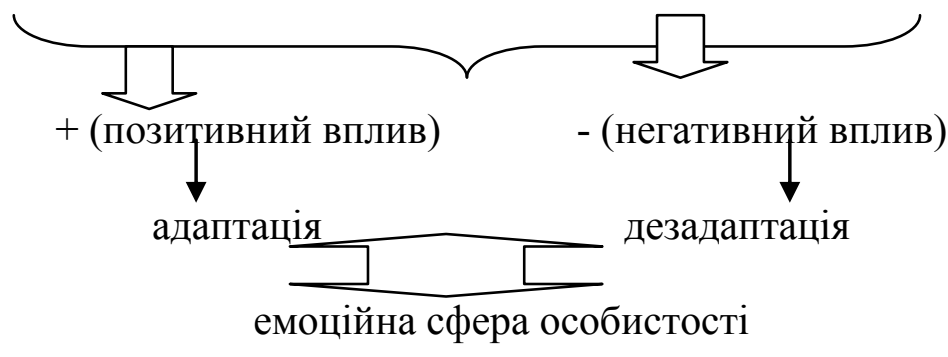

Рис. 1 Основні аспекти адаптації иколяра . 
Таким чином, позитивний вплив біологічних, психологічних і соціальних аспектів сприятиме успішній адаптації першокласника до шкільного навчання. Життєрадісний, бадьорий, живий та веселий настрій молодшого школяра - це певна психофізіологічна норма. Першокласники вчаться управляти своїми настроями, а іноді навіть маскувати їх, що говорить про успішний розвиток емоційної сфери особистості.

При цьому більш стримано виражаються негативні емоції, спостерігається посилення стриманості та усвідомленості в прояві емоцій, підвищення стійкості емоційних станів та вміння володіти собою.

Звідси визначаємо основні складові адаптивності дитини до шкільного навчання (рис. 2).

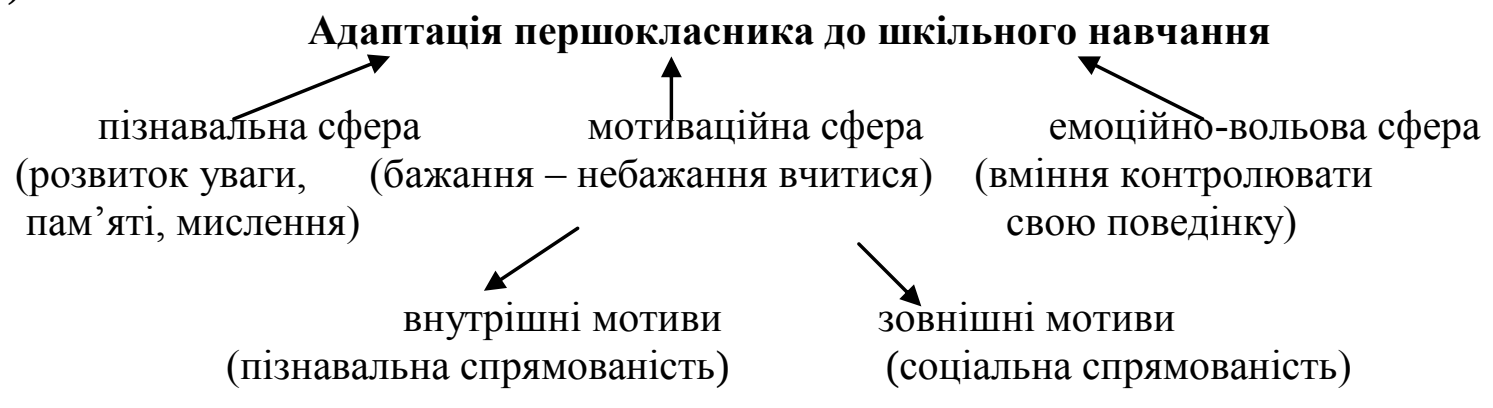

психологічна готовність

\section{Рис. 2 Складові адаптацї̈ до шкільного навчання першокласника}

Проте не у всіх дітей адаптація до школи протікає успішно. Певна категорія першокласників відчуває певні труднощі і процес адаптації у них сильно затягується. Якщо відбувається порушення психосоціального розвитку - з'являється стан емоційного дискомфорту, а це $є$ однією 3 головних причин шкільної дезадаптації та порушення психічного здоров'я школяра. Такі діти часто і довго хворіють, причому хвороби мають психосоматичну природу. У цілому дезадаптовані діти складають групу ризику щодо розвитку відповідних психогеній і дидактогеній, у т.ч. шкільного неврозу. Деякі діти до середини дня навчання виявляються вже перевтомленими, вони стомлюються від великої кількості інформації, що надходить ззовні. При цьому школа для них є специфічним стресогенним чинником. Окрім того, дорога в школу для багатьох потребує підвищеної уваги і напруги. Протягом дня у дітей не буває можливості повного розслаблення, як фізичного, так і розумового та емоційного. Деякі діти невеселі вже вранці, вони приходять до школи перевтомленими, у них 3'являються тривога і страх перед майбутньою роботою в класі, через розлучення 3 батьками тощо. Необхідність спеціального психологопедагогічного супроводу розвитку дітей, які навчаються у початкових класах, гарантує нормальне прийняття ролі школяра, розвиток його пізнавальної активності та закладає потенціал для подальшого становлення особистості учня. Гарна успішність, засвоєння шкільних норм поведінки, відсутність проблем у спілкуванні та емоційне благополуччя вважаються критеріями ефективної адаптації до шкільного навчання. Проте під впливом певного ряду чинників може сформуватися дезадаптація першокласника в умовах навчального процесу. Вона характеризується негативним емоційним відношенням до школи, високим рівнем тривожності, підвищеною емоційною лабільністю, низькою працездатністю, руховим розгальмуванням, а також труднощами спілкування із вчителями й однолітками.

У цілому Головко та Головко виділяють такі варіанти шкільної дезадаптації:

Bapiaнm 1. Дезадаптація, що виникає на фоні особливостей навчального процесу молодших школярів. Відомо, що в молодшому шкільному віці діти засвоюють предметний бік навчального процесу - навички та вміння. Коли процес формування навичок та вмінь проходить важко і непродуктивно, учень починає відставати від програми. Це можна помітити на такому симптомі шкільної дезадаптації, як невстигання. I безперечно, тут величезна провина дорослих (учителя і батьків), що вони неуважні чи байдужі до того, як у 
дитини формуються навички і вміння. Навчання - важкий процес для маленького учня, який ще не вміє вчитися. При цьому дорослі часто-густо забувають про те, що кожна дитина неповторна своїми індивідуальними психофізіологічними особливостями та не завжди враховують в роботі 3 дітьми їх інтелектуальний рівень розвитку та особливості їх психомоторики.

Bapiaнm 2. Дезадаптація як невміння дітей довільно регулювати свою поведінку, увагу та адекватно сприймати навчальні вимоги. Такі учні виконують завдання не 3 власної ініціативи, а внаслідок зовнішньої стимуляції з негативним підгрунтям. Подібне виявляється в емоційних дітей, що відзначаються високою чутливістю, збудливістю, неадекватністю переживань і, відповідно, реакцій. Вони зосереджуються на своїх внутрішніх переживаннях, а отже, виконуючи завдання, роблять безліч помилок, неуважні та загальмовані. Звичайно, це може бути наслідком сімейного виховання - «вседозволеності», тобто діти прийшли до школи $з$ дуже низьким рівнем вольової готовності. Отже, з перших днів такі діти відчувають значні труднощі у навчанні.

Bapiaнm 3. Дезадаптація як невміння дітей увійти у відповідний темп шкільного життя. Ці учні, як правило, фізично ослаблені, часто хворіють, швидко втомлюються, невитримані. Вони пасують перед труднощами та значно недооцінюють свої можливості.

Овчарова П. В. зазначає, що проблема шкільної дезадаптації може проявлятися в різних формах, мати різні причини, наслідки та локус скарг. Перша форма. Несформованість елементів i навичок навчальної діяльності. Причина: індивідуальні особливості інтелектуального розвитку, педагогічна занедбаність. Наслідок: низька успішність. Локус скарг: погана успішність з усіх предметів, недосконале читання, відставання з математики, слабка пам'ять, неуважність, учень мовчить на уроках, боїться відповідати, хоча знає; невпевненість у собі; відносно багато часу на підготовку уроків; тривожність, занижена самооцінка. Пасивність, песимізм; розчарування школою, пропуск уроків, втечі зі школи.

Друга форма. Несформованість мотивації учіння, спрямованість на позашкільні види діяльності. Причина: інфантилізм виховання, гіперопіка, несприятливі чинники, що зруйнували позитивну мотивацію (шкільні міжособистісні відносини, неадекватне оцінювання навчальної діяльності тощо). Наслідок: погана успішність і поведінка на фоні достатньо високого рівня пізнавальних здібностей. Локус скарг: тривога 3 приводу індивідуально-особистісних якостей - повільності, інертності, неорганізованості, стомлюваності, некомунікабельності, егоїстичності, впертості, агресивності, озлобленості, брехливості, страхів і фобій.

Третя форма. Нездатність до довільної регуляції поведінки, уваги та навчальної діяльності. Причина: особливості сімейного виховання (гіперпротекція або домінуюча гіпопротекція), а також подібний тип виховання в дитячому садочку і початковій школі. Наслідок: неорганізованість, неуважність, залежність від дорослих, порушення форм спілкування та слабка успішність. Локус скарг: тривога з приводу особливостей поведінки, навчальної діяльності і спілкування дитини із ровесниками і дорослими, нетовариськість. Замкненість та відсутність друзів; невміння дружини із ровесниками; погані відносини 3 учителями; прояви булінгу; погані відносини між дітьми в сім'ї, відсутність бажання грати із ровесниками, тяжіння до «поганих дітей», нерозуміння дитини. Виділяють приховані форми шкільної дезадаптації: дитина зазнає постійну внутрішню тривогу й страх перед школою й вчителями, у неї відсутнє бажання ходити в школу, спостерігаються труднощі у спілкуванні, формується неадекватна самооцінка, як правило, на фоні гарної успішності й дисциплінованості (Сорокина, 2005).

Відповідно до класифікації, яку запропонувала Безруких, за рівнем адаптованості дітей можна умовно поділити на три групи:

- Перша група (високий рівень) адаптується до школи протягом перших двох місяців навчання. Ці учні відносно швидко входять у колектив, освоюються у школі, знаходять нових друзів у класі, у них майже завжди гарний настрій, вони доброзичливі, сумлінно і без видимого напруження виконують усі вимоги вчителя. Інколи в них трапляються складнощі або в контактах із дітьми, або у стосунках з учителем, оскільки їм ще 
важко виконувати усі вимоги правил поведінки. Але до кінця жовтня відбувається засвоєння і нового статусу, і нових вимог, і нового режиму. Це дозволяе їм із перших днів відчути свої досягнення, що ще більше підвищує навчальну мотивацію. Легка форма адаптації.

- Друга група дітей (середній рівень) має тривалий період адаптації, невідповідність їхньої поведінки вимогам школи затягується; вони не можуть прийняти ситуацію навчання, спілкування $з$ учителем та однокласниками. Як правило, їм важко опанувати навчальну програму. Завдяки доброзичливому і тактовному ставленню вчителя до кінця першого півріччя реакції таких дітей стають адекватнішими. Це форма середнього рівня адаптації.

- Третя група: діти, в яких соціально-психологічна адаптація пов'язана зі значними труднощами. Вони не засвоюють навчальної програми, у них проявляються негативні форми поведінки та домінують негативні емоції. Саме на таких дітей найчастіше скаржаться вчителі та батьки. Постійні невдачі в навчанні, відсутність контакту 3 учителем створюють відчуження і негативне ставлення однолітків. Серед цих учнів можуть бути ті, хто потребує лікування (учні з порушеннями психоневрологічної сфери), проте можуть бути й учні, не готові до навчання у школі. Це т.з. «група ризику».

Створення сприятливих умов адаптації дитини до школи з урахуванням особливостей iii прояву $є$ найважливішим чинником щодо забезпечення наступності в його розвитку. Від того, як протікає процес адаптації, багато в чому залежить психофізіологічний стан майбутнього учня, а також його фізичне і психічне здоров'я. (Безруких, 2005).

Мета статті. Вивчити особливості адаптації молодших школярів до навчального процесу та основні причини їх дезаптації, а також вплив емоційної сфери на успішну адаптацію першокласника до школи.

Виклад основного матеріалу дослідження. У дослідженні приймали участь учні у віці 6-7 років. Обсяг вибірки нараховував 74 дитини контрольної групи та 26 дітей експериментальної групи. В основі нашого дослідження лежить особистісний підхід щодо розуміння процесу адаптації першокласника до навчального процесу. Кроком по дослідженню рівня адаптації першокласників була методика «Дерево» Пономаренко. Учням пропонувались листки із зображенням сюжету: дерево і розташовані на ньому фігурки людей. Кожен учень отримував листок з таким зображенням (але без нумерації фігурок). Завдання звучало так: «Роздивіться дане дерево. Ви бачите на ньому і поряд 3 ним багато фігурок. У кожної 3 них - різний настрій і вони займають різне положення. Візьміть червоний олівець і обведіть ту фігурку, яка нагадує вам себе, схожа на вас та ваш настрій в школі. Зверніть увагу, що кожна гілка дерева прирівнюється вашим успіхам та досягненням. Тепер візьміть зелений олівець і обведіть ту фігурку, якою б ви хотіли бути і на чиєму місці ви хотіли б знаходитись».

Інтерпретація результатів проективної методики «Дерево» проводилась, виходячи 3 вибраних позицій учнів, позицій кожної фігурки на малюнку, які ототожнювали реальне та ідеальне розташування на дереві, а також аналіз різниці між ними. За результатами дослідження, 53 \% учнів експериментальної групи та лише $21 \%$ контрольної групи має високий рівень адаптації. Ці діти відносно швидко входять у нове соціальне середовище, добре освоюються в школі, знаходять нових друзів в класі, у них майже завжди гарний настрій, вони доброзичливі, сумлінно і без видимої напруги виконують усі вимоги вчителя. Іноді в них відмічаються складності або в контактах 3 дітьми, або у стосунках з учителем, оскільки їм ще важко виконувати всі вимоги правил поведінки. Але до кінця жовтня відбувається засвоєння і нового статусу, і нових вимог, і нового режиму. Ці якості дозволяють їм 3 перших днів відчути свої успіхи, що ще більше підвищує навчальну мотивацію. Необхідно звернути увагу на першокласників, які показали низький рівень адаптації (10\% - контрольна група, 5 \% - експериментальна група). Це проявляється в порушенні дисципліни, зниженому інтересу до навчальних занять, у наявності труднощів регулювання поведінкою, уваги та навчальної діяльності, в невмінні пристосовуватись до темпу шкільного життя. Це діти, в яких соціально-психологічна адаптація пов'язана із значними труднощами. Вони не засвоюють навчальну програму, у них проявляються негативні форми поведінки, різкий прояв негативних емоцій. Саме на таких дітей найчастіше 
скаржаться вчителі та батьки. Інші діти мають середній та достатній рівень адаптації, період невідповідності їхньої поведінки вимогам школи затягується: діти не можуть прийняти ситуацію навчання, спілкування з учителем і дітьми. Як правило, ці діти зазнають труднощі в засвоєнні навчальної програми. Завдяки доброзичливому і тактовному відношенню вчителя до кінця першого півріччя реакції цих дітей стають адекватними шкільним вимогам.

Висновки та перспективи подальших розвідок. Для підвищення рівня адаптації на основі розвитку емоційної сфери доцільно проводити т.з. кольорові експерименти, які допоможуть сформувати позитивне ставлення першокласника до навчання в школі. Для цього необхідно запропонувати батькам та вчителю урізноманітнити соціальне середовище, в якому перебувають учні в школі та вдома, за допомогою певних кольорів (розбудова «будиночків» позитивних емоцій). Наприклад, можна разом із школярем виготовити червоні чи жовті (колір вибираємо відповідно до результатів діагностування) сердечка і квіточки та розмістити їх у кімнаті, де учень навчається. Даний експеримент за допомогою кольору може ефективно вплинути на емоційну сферу першокласника, сформувати запас позитивних емоцій щодо навчального процесу та підвищити рівень шкільної адаптації. Подібні психофізіологічні експерименти є перспективою щодо подальшої роботи з даного напрямку.

\section{СПИСОК ПОСИЛАНЬ}

Аминникова, Н. С. (2006). Адаптация первоклассников к школьным условиям. Фестиваль педагогических "Открйытый й урок". Взято с http://festival.1september.ru/articles/314289/

Безруких, М. (2005). Готов ли ребенок к школе? Москва: Вентана-Граф.

Луговых, Т. А. (2008). Диагностика адаптации первоклассников к школе. Фестиваль педагогических идей "Открытый урок". http://festival.1september.ru/articles/511644/

Сисоєнко, Н. (2005). Особливості адаптації молодших школярів до навчального навантаження в сучасних загальноосвітніх закладах різного типу. Актуальні проблеми гігієни праці, професійної патологї і медичної екологї Донбасу. (с. 372-374). Донецьк: Каштан.

Сорокина, В. (2005). Психологическое неблагополучие детей в начальной школе. Диагностика и пути преодоления. Москва: Генезис.

Степник, О. (2007). Причини шкільної дезадаптації. Психологічна газета, 14 (86).

Юрченко, И. (2009). Социальная адаптация детей к школе. Проблемы психологической адаптации личности в разных видах жизнедеятельности: материалы Всеукраинской научно-практической конференции молодых научных сотрудников. Одесса: СМИЛ.

James, W. (2008). Talks to Teachers on Psychology And to Students on Some of Life's Ideals. Manor. Rockville, Maryland.

\section{REFERENCES}

Aminnikova, N. S. (2006). Adaptatsiya pervoklassnikov k shkolnym usloviyam [Adaptation of the first-graders to school conditions] Festival pedagogicheskikh idey "Otkrytyy urok". Vzyato s http://festival.1september.ru/articles/314289/ [in Russian].

Bezrukikh, M. (2005). Gotov li rebenok k shkole? [Is the child ready to school?]. Moskva: VentanaGraf. [in Russian].

Lugovykh, T. A. (2008). Diagnostika adaptatsii pervoklassnikov k shkole [ Diagnostic of the firstgraders' adaptation to school] Festival pedagogicheskikh idey "Otkrytyy urok". Vzyato s http://festival.1september.ru/articles/511644/ [in Russian].

Sysoienko, N. (2005). Osoblyvosti adaptatsii molodshykh shkoliariv do navchalnoho navantazhennia v suchasnykh zahalnoosvitnikh zakladakh riznoho typu [Peculiarities of the adaptation of the younger schoolchildren to study load in modern general educational institutions of various types]. Aktualni problemy hihiieny pratsi, profesiinoi patolohii $i$ medychnoi ekolohii Donbasu. (s. 372-374). Donetsk: Kashtan. [in Ukrainian]. 
Sorokina, V. (2005). Psikhologicheskoye neblagopoluchiye detey v nachalnoy shkole. Diagnostika i puti preodoleniya. [Psychological deprivation of the children in junior school. Diagnostic and the ways of overcoming]. Moskva: Genezis. [in Russian].

Stepnyk, O. (2007). Prychyny shkilnoi dezadaptatsii [The reasons of school maladjustment]. Psykholohichna hazeta, 14 (86). [in Ukrainian].

Yurchenko, I. (2009). Sotsialnaya adaptatsiya detey k shkole [Social adaptation of children to school]. Problemy psikhologicheskoy adaptatsii lichnosti $v$ raznykh vidakh zhiznedeyatelnosti: Materialy Vseukrainskoy nauchno-prakticheskoy konferentsii molodykh nauchnykh sotrudnikov. Odessa: SMIL. [in Russian].

James, W. (2008). Talks to Teachers on Psychology And to Students on Some of Life's Ideals. Manor. Rockville, Maryland. [in English].

\title{
THE INFLUENCE OF ADAPTION PROCESS OF THE YOUNGER STUDENT TO THE STUDY ACCORDING TO HIS EMOTIONAL EDUCATION
}

Liudmyla Kriukova

PhD student of the Department of Lifespan \& Pedagogical Psychology

Rivne State University of Humanities

ORCID iD: 0000-0001-6572-6214

DOI https://doi.org/10.35619/prap_rv.vi13.123

\begin{abstract}
This article tells us about the peculiarity of the adaptation of the elementary schoolchild to the educational process. The last researches on this topic were analyzed. It was also marked that given problem gained substantial significance at the present stage of the evolution of pedagogical science. We reached the conclusion that developmental level of the emotional sphere of the child rated how adaptive that child could be to the relevant environment. The reasons and forms of maladjustment of the first-grade pupils are determined. The key aspects of the schoolchild's adaption are highlighted.

The main components of the child's adaptability to the educational process are considered. It is determined that a state of emotional discomfort is one of the causes of the school maladjustment and the disturbance of mental health. It is pointed out that the process of adaptation will be taking place faster and more effective under positive development of emotional sphere of the first grader. It is suggested to increase the level of adaptation on the basis of the development of the emotional sphere to carry out color experiments which would help to form the positive attitude of the first-grade pupil to the process of studying at school. Such color-assisted experiments could affectively effect on the emotional sphere of the first-grader, form a store of positive emotions according to the educational process and to make the level of the school adaptation higher.

Key words: adaption, emotional sphere, emotional stability, disadaption, education, firstgrade pupil.
\end{abstract}

